\title{
Finding a place for Jesus as healer in Reformed mission in Africa
}

Author:
Ignatius W.C van Wyk ${ }^{1}$
Affiliation:
'The Africa Institute for
Missiology, Reformed
Theological College, Faculty
of Theology, University of
Pretoria, South Africa
Correspondence to:
Natie van Wyk
email:
aim1@mweb.co.za
Postal address:
PO Box 32186, Waverley
0135, South Africa
Dates:
Submitted: 21 May 2010
Accepted: 17 July 2010
Published: 07 June 2011
How to cite this article:
Van Wyk, I.W.C., 2011,
'Finding a place for Jesus as
healer in Reformed mission
in Africa', HTS Teologiese
Studies/Theological Studies
$67(1)$, Art. \#864, 8 pages.
DOI: $10.4102 /$ hts.v67i1.864

(C) 2011. The Authors. Licensee: OpenJournals Publishing. This work is licensed under the Creative Commons Attribution License.
Africa is a continent plagued with many sicknesses and diseases. Self-evidently health and healing would be major concerns and interests of the inhabitants.

Reformed mission has formed a strategic alliance with scientifically tested medicine in the past. Africans do not find this alliance sufficient. They, however, need a medical mission that could deal with 'African sicknesses'. The question is whether we need an alliance with traditional medical practitioners. Because traditional healing is linked to traditional religion, we are confronted with difficult missiological questions.

The solution offered in this article concentrates on two dimensions, (1) an openness to and a respect for African culture and religion and (2) a radical rediscovery of Jesus as healer.

\section{Introduction}

By simply looking at the biblical reports, one expects the healings, exorcisms and miracles of Jesus to be at the centre of any theology of the New Testament and dogmatic Christology. Sadly, in wellknown European contributions of the past century, this does not seem to be the case. ${ }^{1}$ On account of the biblical reports (as sermons), it is clear that the pre-Easter Jesus should, to a large extent, be understood as healer. There are simply too many references to his healings and exorcisms in the Gospels to ignore them as being insignificant (cf. Craffert 1999; Etzelmüller \& Weissenrieder 2010). It is furthermore clear that the healing activities of Jesus as imbedded in his own mission have formed the background to the earliest missionary reactions and actions of believers. ${ }^{2}$

The missionary commissions of the pre-Easter Jesus are also linked to healing activities. The 'twelve' (Lk 9:1-9) and the 'seventy-two' (Lk 10:1-24) who were sent out to become fishers of men and to preach the coming of the Kingdom were empowered to perform all kinds of healings. ${ }^{3}$

The first missionary movement, initiated by the apostles, also concentrated on a combination of proclamation and healing. The work of Peter and Paul, as documented in the Book of Acts, ${ }^{4}$ needs special mention. Early in the history of the church, healing was interpreted as a gift of the Holy Spirit (1 Cor 12:7, 9, 28). One should also keep in mind that the early church was a healing community. The elders prayed for the sick and anointed them with oil in the name of the Lord (Ja 5:14 - cf. Rt 3:3; 2 Sm 14:2; Dn 10:3). It is therefore clear that the first believing communities trusted in 'faith healings' (Ja 5:15) as well as the 'magical power' of sacred substances (Berends 1998:6).

Throughout history, the church has made an enormous contribution towards health, healing and healthcare. The achievements of the church in this regard are well documented (cf. Porter 2007). We as South Africans, with our small perspective of history, cannot form a proper image of the contribution of the church during the Middle Ages. The church made positive contributions to every possible effort regarding medical science and medical care (cf. Jankrift 2003, 2005). For the purposes of this article, I wish to highlight only the following achievements of the church during the mediaeval period of history ${ }^{5}$ :

1.Bultmann (1977, 1980a), Goppelt (1978), Pannenberg (1991), Stuhlmacher (1992) and Van de Beek (1998) refer only here and there to Jesus' healings, whilst Gnilka (1990), Kasper (1993), Moltmann (1989) and Ridderbos (1972) have longer expositions. Some of them (Bultmann 1980b; Van de Beek 1991), however, wrote important essays and books on this theme.

2.The following verses from Luke should proof the point: $4: 14 ; 5: 1-11 ; 5: 17-26 ; 7: 18-35 ; 8: 26-56 ; 9: 10-17 ; 9: 37-45 ; 11: 14-28 ; 13: 32$; 18:35-43; $19: 37$.

3.After Jesus had called his disciples to become fishers of men (Lk 5:1-11), he immediately healed someone $(5: 12)$. He sent out the twelve not only to preach but also to heal the sick. He gave them the power and authority to do so (9:1-9). It is important to note that the disciples could not heal a child with epilepsy $(9: 37-45)$. They were not sent out as magicians. A man who was not a disciple drove out demons in the name of Jesus. Healing miracles were not (and still are not) the privilege of only a few (9:46-50). The $72 \%$ were sent out to preach the coming of the Kingdom. However, Jesus also gave them the power to heal the sick. Importantly, the emphasis was not on the power over evil but on the message about salvation that needed to be revealed to ordinary people (10:1-24).

4.Cf. at least Acts 3:1-10; 4;30; 5:12-16; 8:4-7; 9:32-43; 10;38; 14;9: 28;27 (cf. Kahl 2010 for comprehensive information).

5.African theologians should also take cognisance of the enormity of the Western Christian contribution to health, healing and healthcare. The anti-Western, anti-European propaganda concerning the anti-holistic medical approach (cf. Manda 2008; Rukuni 2007) does not The anti-Western, anti-European propaganda concerning the anti-holistic medical approach (cf. Manda 2008; Rukuni 2007) does not
benefit the efforts to facilitate an open dialogue on healing in a pluralistic society (cf. Van Wyk 2009b for an attempt at intercultural debate). 
- Answers to all the major philosophical questions regarding diseases, pandemics and catastrophes.

- The development of a variety of hospitals, tending to every possible sickness and disease in a comprehensive and holistic way.

- The development of the nursing profession, grounded in the deaconate of the church.

- An enormous contribution to medical scientific research.

- Experimenting with all kinds of traditional, indigenous medicines and healing practices that could benefit the sick and the dying.

It is noteworthy that at least two of the leading Reformers of the 16th century, namely Philipp Melanchthon and John Calvin, made valuable contributions to the question concerning the relationship between faith and healing. Melanchthon ${ }^{6}$ deserves special acknowledgement for paving the way for the close relationship between faith and scientifically tested medicine as well as for the cooperation between the faculties of Theology and Medicine in Wittenberg (cf. Oehmig 2007).

Since the Reformation, European churches have had no difficulty in combining mission and 'Western scientific medicine'. 'Medical missions ${ }^{\prime 7}$ proved to be a successful missionary approach in Africa (Sievernich 2009:98-101). However, one should concede that this approach has also become one of the major stumbling blocks of Reformed mission in Africa. African people welcome the efforts of mainline Protestant churches to enhance health with the support of 'Western scientific medicine'. However, they do not regard this campaign as being sufficient. They also want to experience an alliance with traditional African medicine and healing practices. The urge is for a more holistic approach that would deal with all the African health problems, including witchcraft, spiritual affliction and the typical African stress-related sicknesses. The exclusion of traditional healing practices as well as the traditional African world view from mission has undoubtedly become a stumbling block to African Christianity (cf. Manala 2006).

In European or Northern Christianity, the dominance of the scientific world view has made theologians believe that not only primal religiosity but also the biblical reports on healing miracles should be excluded from theological reflection. This type of theology has directly or indirectly influenced missionary efforts in Africa. The time has come to acknowledge that a theology with a weak interest in healing does not capture the imagination of Africans. The absence of

6.Philipp Melanchthon (1497-1560) the Rector of the University of Wittenberg during Martin Luther's lifetime, reformed and transformed not only the study of theology but also the study of medicine. In his handbook Commentarius de anim (1540), rewritten as Liber de anima (1552), he combined anatomy and Protestan theology. Before 1540, anatomy was a pure natural science. Melanchthon, however, convinced the medical faculties in Wittenberg and Leipzig to lecture on the medical sciences within the framework of a broader biblical understanding of humanity and its world. He also advised the theologians to study biblical anthropology whilst keeping the knowledge of the medical sciences in mind (cf. Helm 2007). The important point is that Melanchthon was of the opinion that theology should interface with the wisdom and knowledge of the world. My critical question is why is it allowed to interface with Western medical science but not with traditional knowledge systems? (cf. Hoppers 2002 for the plea from the Third World).

7.Interestingly, the last joint missionary effort between the Nederlandse Hervormde Kerk (through the Gereformeerde Zendingbond) and the Nederduitsch Hervormde Kerk van Afrika concentrated on the work in the hospital of Eldoret, Kenya (cf. Van den End \& Van't Veld 2001:107-110). significant church growth in the mainline Reformed churches over the past five decades is proof of this. ${ }^{8}$

African Initiated Christianity (AIC) and African Pentecostal churches, however, have shown enormous growth over the same period of time. One reason for their 'success' certainly has to do with their healing ministries. These churches have succeeded in combining elements of traditional healing with the gospel. AIC has successfully indigenised the healing message of the New Testament with the realities of African traditional culture and religion (cf. Anderson 2001:233-238; Du Toit \& Ngada 1999). Even the Pentecostal churches claim that they have managed to combine Africa's primal religiosity with the New Testament message (cf. AsamoahGyadu 2008).

The question that needs to be answered is why African scholars and churches try to reconcile Christianity with traditional healing. At least the following perspectives need to be mentioned: Africa is known for its many diseases and pandemics. Self-evidently, the search for health, healing and a good life calls for great urgency. For centuries, African traditional religion and the traditional healing practices accompanying it have helped Africans to deal with sickness and death. It needs to be accepted that the African masses have not and are not going to turn their backs on the proposition of traditional healing completely. It is also well known that 'Western medicine' has not as yet come up with an effective treatment for the HIV and AIDS pandemic. As long as this is the case, Africans will embrace medical pluralism. I am therefore of the opinion that Reformed mission could continue to transfer elements of European medical achievements (inter alia as fruits of the biblical message) to Africa but that it should also try to liaise with traditional healing. The time is past for African culture and religion, in its totality, to be viewed as irreconcilable with the Christian faith. Africans have, over the past decades, become 'proudly African'. Reformed mission should therefore not ignore this epoch-making cultural transformation process. We would have to find a way in Reformed missiology for the removal of the tendency of being anti-African. This new approach would have to include a more accommodating attitude towards traditional healing. As Reformed theologians, we would subsequently have to critically revisit our traditional viewpoints on the relationship between the Christian faith and traditional healing. We would have to accept the following facts:

- Africans are not going to despise their own culture, which is inextricably intertwined with traditional religion.

- Traditional healing practices, which are imbedded in traditional religion, will remain an important aspect of African life.

- The Christian faith would have to accommodate at least certain aspects of traditional healing.

- Western allopathic medicine cannot be the sole legitimate partner of missionary efforts.

8.The mainline Reformed churches did not grow as expected. In South Africa, the The mainline Reformed churches did not grow as expected. In South Africa, the
'mission churches' of the Afrikaans-speaking Reformed churches comprise only 5\% of the population and 7\% of Christianity (cf. Kalu 2005:24; Kritzinger 2002:15-18). 
- The plurality of medical opinions and options would have to be respected by the church's mission.

\section{European and African theologians on healing}

I will briefly revisit a few opinions that could assist us in obtaining clarity on the fundamental problems we are facing. Firstly, I will discuss the opinions of three New Testament scholars who are exemplary of the church's struggle with the Enlightenment and its consequences. I will also indicate why these opinions are not helpful in respect of the missionary task in Africa. Secondly, I will discuss the opinions of a few African scholars who are attempting to accommodate aspects of primal religiosity. I will, however, also mention my own reservations concerning their opinions.

\section{New Testament scholarship and the scientific world view \\ Rudolf Bultmann and miracles}

According to the sociologist Max Weber (1864-1920), the task of science is to deprive the world of its mystique (Entzauberung). Rudolf Bultmann embraced this theory and made it the goal of his demythologisation program. In line with the credo of the sciences of the 20th century, he believed that one had to eliminate miracles, explain the explainable and make the unexplainable explainable. The result of this rationalisation and demythologisation process was the creation of a new myth, namely the possibility of complete scientific insight into and knowledge of reality (Pernkopf 2007:28). However, this assumption is not reconcilable with Jewish-Christian thought, as will be argued later.

Bultmann, who was deeply influenced by modernism, had a deprecatory attitude towards faith healing and miracles. His opinions are not helpful in the African context. Africans have little difficulty believing in the supernatural, spirits, miracles and magic. As South Africans living in a country where the First and Third worlds meet, we cannot opt for either the one or the other paradigm. We need a midway of dealing with the biblical reports and our scientific and traditional environments. I believe that early Greek philosophy and Jewish religion provide us with acceptable avenues.

Allow me to start with a perspective from the Jewish tradition. More often than not it has been stated that the Old Testament is the Bible of Africa (Ntloedibe 2000). As Reformed theologians we could never reconcile ourselves with this anti-Christological theology. We should, however, give the Old Testament (and the Jewish cultural tradition) the attention it deserves. Even regarding this matter, the Old Testament may assist us in finding a way to Jesus Christ as well as to discovering the necessity for scientific research. According to the Jewish tradition, the Torah and the community of the elect play a decisive role in terms of life orientation. Whatever falls outside of these perspectives should be left to the 'course of life' and should be handled with common sense and the sciences. It is therefore not strange that Jews have made an enormous contribution to medical science without having produced a stream of charismatic healers. Many Jewish philosophers and theologians had been physicians and medical researchers. One would not easily find magicians and miracle workers in the mainline Jewish tradition. There is obviously another reason for their disinterest in magic, namely the faith in $\mathrm{JHWH}$ as healer ${ }^{9}$ (cf. Maier 2007:63-70; O'Kennedy 2007). Importantly, according to Jewish belief, God heals those who obey the Torah and health and healing have therefore to do with a lifestyle of obedience to God's law (cf. Ex 15:22-26; Lv 26:11; Is 65:20). In addition to faith in JHWH, the support of the community of the elect is of utmost importance. Prayers during worship service, diaconal support of the affected family as well as visits in hospitals (cf. Maier 2007:80-84) support the faith of the believer. What more could be done? What more could be included in a 'holistic approach to healing'?

According to Plato and Aristotle, astonishment ['verbasing'] and amazement ['verwondering'] lead to philosophy. Thaumazein, understood as astonishment and amazement, is therefore the road on which one would encounter the miracle, the miracle of the fact that something is and that there is not simply nothing (cf. Esterbauer 2007:19). Leading scholars in the natural sciences today state openly that they are also cautiously feeling their way through their research. They are also subjected to guessing, doubting and hoping. The idea of a 'miracle' is no longer a taboo topic. They are also looking at reality with amazement, allowing the unexpected to guide their imagination and their thinking (Pernkopf 2007:39). We as theologians should therefore stop fearing and bring back the concept of miracles into our theological discussions. Self-evidently, the reason for our amazement would be because we have heard about the deeds of Jesus from reliable witnesses.

A Jewish dictum states, 'A Jew is not a Jew when he does not expect a miracle every day'. This is a statement not only about the power of God but also about the relativity of human actions. This dictum states verbatim what the symbol of the Jewish 'hat' is referring to, namely that God, His power and His actions relativise all our human efforts. The miracle undermines the absoluteness of our planning and constructions. The belief in miracles liberates us from fantasies about human omnipotence and from our concern of having to do everything and our ability or disability to do it. The belief in miracles simply states the willingness to reckon with God in our human history (Rapp 2007:41-43). 'Praise be to the Lord God, the God of Israel, who alone does marvellous deeds' (Ps 72:18).

Amazement at what God has done and is still doing in Christ seems, in my opinion, to be a more responsible approach to healing. The desire, on the one hand, to see magic visibly at work (African religiosity) whilst rejecting divine intervention in history (Western science), on the other hand, would not be responsible. True faith and the willingness to witness are clearly linked to amazement and awe (cf. Mt 9:8; Lk 5:26;

9.Cf. Genesis 20:17, Exodus 15:26, Numbers 12:13, Deuteronomy 32:39 and Psalms 103:3. 
7:16; Ac 2:43). A theology and church giving up on talking about healing miracles have given up on talking about God. In Africa, talk about the providence of the ancestors cannot be the theologian's main interest. Should people not be filled with astonishment and amazement at the miraculous deeds of God in Christ, the shift of the centre of gravity of Christianity to the south (cf. Jenkins 2007) would be nothing more than a momentary object of scholarly excitement.

\section{Walter Schmithals and the historical Jesus}

According to the viewpoint of Walter Schmithals (1970:25), the New Testament only reports on the miracles as seeming events from the life of the earthly Jesus. In fact, it preaches about what God has done for His congregation and what $\mathrm{He}$ wants to do for the world through Jesus Christ, the crucified and resurrected Lord. This viewpoint puts Schmithals in the comfortable position of not having to discuss the historical validity of these reports. In the process, these reports are degraded to being accidental and artificial fittings for the Gospel (Kerygma) that are not grounded in the historical deeds of Jesus (Weder 1992:63). The end result would be that we would have nothing more than the 'word about the cross and resurrection' to present to the world. Furthermore, Schmithals is of the opinion that it is not important who the historical Jesus was; it is only important who He is now. The question is, Should we use this opinion for our missionary effort in Africa? I do not think so. In Africa, the question who someone was, where he came from and who his ancestors were is of the utmost importance. The same can be said about the Jews. ${ }^{10}$ The historical Jesus, his historical background and his historical deeds are important aspects of mission in Africa. Kwame Bediako (2000:23) refers to the argument of the critics of Christianity that Jesus is a latecomer in Africa. In Africa, people respect that which is old. The first ones, the founders, the progenitors, the ancestors are regarded as the important ones. In terms of a mission strategy, it would be important to refer to Jesus as the pre-existent Son of God, the Son of Man, the Son of Abraham, the Son of David who is much older than any African ancestor. The Jesus who healed the sick and who is still present as healer should be presented as a historical personality and reality. The healings of Jesus only as signs of the future Kingdom do not impress Africans. To them, what He has done in the past is more important than any promises about actions in the future.

\section{Andries van Aarde and the reality of spiritual affliction}

Andries van Aarde is of the opinion that Jesus' healings and exorcisms should be understood against the background of the stress factors ${ }^{11}$ of the first-century Mediterranean world. According to him, they were 'healings of empowerment'. Jesus empowers people to cope with stress. Van Aarde (2000) states the following:

Jesus 'empowered' people who succumbed to stress and enabled them to survive. He provided renewed sense and meaning to people's lives. Jesus' healings were not miracles in the sense of a supernatural intervention by God in the physical world; rather,

10.The genealogies of Jesus (Mt 1 and Lk 3) are vitally important to a Christology in Africa.

11.These stress factors are intrafamilial conflict and the levy of taxes by the Roman regime. The factors giving rise to demonic possession are social stress, economic exploitation, labelling and colonial domination (cf. Van Aarde 2000:227-232). they are part of God's engagement with the social world and lives of people. A miracle is not God's periodic interference with a closed natural order. It is, rather, the permanently hidden yet continual and uninterrupted heartbeat of the natural. It is present to those who see and hear it with the eyes and ears of faith.

(Van Aarde 2000:223)

The empowerment miracles of Jesus help the sinners and other social outcasts to transform from a nobody into a somebody. Through experiencing the love of God through Jesus' 'psychotherapeutic' deeds, they could carry on with life with new sense and meaning.

(Van Aarde 2000:234)

This is an attractive theory. It is a known fact that many diseases can be linked to stress factors. The critical question, however, is whether this interpretation has not also been shaped by a Western modernistic world view. Does this theory do justice to the biblical reports and would it appeal to Africa?

I have reason to believe that the non-African concept of 'empowerment' would not satisfy the needs of African people. Empowerment is an ethical concept that relies on the idea of individual freedom and choice; this is exactly what is nonexistent in a traditional setting. Furthermore, the need for deliverance relates to powers of a transethical nature. For this reason, Africans do not have the urge for demythologisation, as evil and demonic powers are living realities to them (Manala 2006:3, 10, 285). In most cases, stress-related mental disorders are ascribed to attacks from the 'spirits-of-theabove'. An anti-supernaturalistic rationalism that explains possession in terms of mental pathologies would not touch the heart of Africa's problems. Responses to 'spirit attacks' are limited to three possibilities, namely appeasement, accommodation and exorcism. Obviously, the biblical reports on Jesus' exorcisms would be of exceptional missiological importance (Ferdinando 1999:55-59, 70-85).

\section{African scholarship and primal religions}

\section{Jesus the life-giver and the theodicy problem}

Regarding the question what the main contribution of African Christology could be, Kwesi Dickson (Stinton 2004:54), President of the All African Council of Churches, states that African scholars could contribute to the understanding of the notion of Jesus as the giver of life (Jn 10:10). According to him, the images of Jesus as the giver of bread, water and light (Jn 6) could be afforded a wider and better understanding through referrals to Africa's understanding of life, culminating in society's participation in social structures and the successes of keeping families together (Stinton 2004:55-56). John Pobee supports this effort when he states that the image of Jesus as the life (Jn 14:6) could be explained to Africans through using the seven graces in Akan life as the context of understanding. He believes that when Ghanaians hear that Jesus provides good health, grace, peace in society, potency and fertility of sex, powerful eyesight, good hearing, rain and general prosperity to the clan, they would join the church (Stinton 2004:58). African theologians should not shy from proclaiming Jesus as healer because Africa is a continent of many diseases. The many deaths and lack of good living conditions are the reasons why Christ as healer would be 
important to Africa. One could even state that faith in Africa is an 'act of desperation'. A message about a powerful divine being that could heal and provide would without a doubt appeal to the African masses.

However, Bénézet Bujo (Stinton 2004) realises that theologians are constantly confronted by the theodicy problem when he writes as follows:

Jesus Christ is thus conceived by many African Christians as the great physician, healer and victor over worldly powers par excellence. To many, Jesus came that we might have life and have it more abundantly. But the perturbing question is, where is the abundant life, when all around us we see suffering, poverty, oppression, strife, envy, war and destruction?

(Stinton 2004:62)

One of the answers to this question that one encounters increasingly is that diseases (such as HIV and AIDS) should be seen as the punishment of the ancestors for Africans' embracement of the Christian faith and their loss of interest in ancestral religiosity (Ferdinando 1999:53; Van Dyk 2008:201-206). This answer is an effective tool in the hands of the African Renaissance Movement (cf. Muendane 2006), which is spreading fast over Africa. The problem is, of course, that the theodicy question would not go away, no matter how many cows are being sacrificed to the ancestors. The ancestors simply are not reliable providers of health and food.

Interestingly, the Jewish tradition knows of many 'punishment miracles'. Jesus, however, did not perform such miracles. Why not? The function of these punishment miracles has always been the sanctioning of the current construction of reality. These miracles, therefore, have made cultural innovation impossible. The miracles of Jesus, however, make a new interpretation of reality possible (Weder 1992:69, 74). Hopefully, this perspective would illuminate my plea that the importance of Jesus' healings be reconsidered. One of the main problems with the African world view is that it leaves little room for innovation and something new. The complaint that the church wants to foist a newcomer on Africa is typical of a 'closed world-view' that fears anything new.

However, we would have to refrain from a misplaced idealism in Africa. The negativity of traditionalists towards Christianity also has to do with an observation of reality that Europeans find difficult to understand. Africans realise the brokenness of the fallen world. They know that not everything could be repaired or made possible. In Africa, one becomes overwhelmed by the enormous powers and forces of society and nature. Sadly, Africa believes that 'blaming' (Van Wyk 2004:1221-1222) would solve problems. However, it does not solve problems; it multiplies them. The Gospel could assist in accepting the mysteriousness of this world. Furthermore, it could also help to discover sin (original sin) and the consequences of sinful actions as the reasons behind our social problems. ${ }^{12}$ This discovery could resultantly have an influence on many other things. People would stop spreading the HI virus. They would stop the collapse of

12.This is one reason why elenctics, to my mind, should form part of the curriculum. the medical infrastructure. They would patiently wait for scientific solutions to this seemingly incurable disease ${ }^{13}$ and be open to divine intervention into our world.

\section{Jesus in alliance with traditional healers}

African theologians such as Jean-Marc Ela have a different strategy in mind for dealing with Africa's health problems. Ela believes that the church should seek an alliance with the traditional healing fraternity. We should allow the gospel to speak to Africans through their primordial symbolism, as 'Western' medical science is not regarded as the sole or best solution to the health crisis in Africa. The vast majority of African people still consult traditional healers because the Western health care system does not address the typical African problems of evil, witchcraft and misfortune. The result is that Christians have a dualistic approach to sickness and disease. Ela complains as follows:

Christians, you unfortunate people! In the morning at mass, in the evening at the diviner's! Amulet in your pocket, scapular around your neck! This Zaïroise song reveals the tragedy of the majority of black African Christians ... For a great number of baptised people, conversion to the Gospel is a veritable, ambiguous adventure.

(Ela quoted from Stinton 2004:63)

The solution, as Ela and some of his compatriots see it, would be to form an alliance with traditional healing and healers. These theologians are convinced that the church should work its way into the cultural fibre of African society. By forming a close alliance with traditional culture and religion, one could deal with the typical African health problems in a holistic and culturally acceptable way. Uchenna Ezeh (2003:280-284) explains this conviction: In Africa, misfortune such as sickness, barrenness and mental illness is seen as coming from evil spirits (mostly controlled and utilised by evil-minded people) or angry ancestors. People therefore believe that illness has not only physical but also spiritual causes. The spiritual causes could be distorted relationships with people or the ancestors (due to familial or sacrificial negligence or the transgression of a taboo) or the irrational behaviour of malicious spirits. Sicknesses and diseases are therefore believed to have socio-moral and mystico-spiritual causes. Health and healing should accordingly be imbedded in the 'magico-religious fabric' of society. Traditional healers, as well as Jesus, could contribute to a holistic healing process. The physical, spiritual and social dimensions of life could receive attention. Natural as well as supernatural problems could be dealt with by a dual onslaught on the sickness. A variety of healing methods (the use of medicine, magic, prayer, sacrifices, exorcist rituals and counselling) would provide a better chance for recovery.

This solution might seem acceptable at first glance but, in fact, is very problematic. From a missiological point of view, the major question would be 'is there a place for Jesus in

13.It is not the first time that a society is being confronted with a seemingly incurable disease. The 'French disease' or syphilis had the same impact on Europe (14971501). The medical fraternity had the confidence at the time that they would $1501)$. The medical fraternity had the confidence at the time that they would
eventually come up with a solution. This episode should encourage hopeless eventually come up with a solution. This episode should encourage
people in Africa (cf. Stein 2007 for information on the struggle in Leipzig). 
this approach'? Traditional healing is linked to traditional religion and therefore these healers rely on the ancestors (or God) but not on Jesus for assistance. The counter-argument would be that many European doctors are atheists and why would it be a problem to consult them? Here, the importance of the First Commandment comes into effect. Ultimately we would have to make the following choices: Do we still want to defend the exclusivity or the absoluteness of the Christian faith, or would we be willing to accept the syncretistic nature of African Christianity as the best possible solution?

Should we choose the road of exclusivity, we would have to work with the image of Christ as the powerful healer, the Christus Victor of the New Testament (Ac 10:38) and the early church (Aulén 1970:36-60). As Reformed Christians, we are hesitant to expect too much from prayer because of the importance of the petition 'Thy will be done'. We would have to keep in mind that in Africa, the struggle is between two religions. In the struggle for survival and dominance, one cannot enter the discourse with a 'weak Christ'. Jesus the healer, the Son of the Almighty God, is important in Africa (Stinton 2004:66-69).

Some African scholars (cf. Stinton 2004:80-103) are proposing another solution to the problem when they portray Jesus as healer (Ngaka). By doing so, they use the known, accepted and respected imagery as missiological vehicle. The aim is also to communicate something of the comprehensiveness of Jesus' healings. A diviner ${ }^{14}$ (so we are told) follows a more holistic approach to sickness. His importance lies in the reconstruction of the social reality of a sickness.

This type of indigenisation is not new. In early Christianity, Jesus was portrayed as the new Asclepius. He was called Christus medicus (Honecker 1985:310-314). This Christology was never widely accepted because Jesus is more than and different from the great healers of Hellenism (Honecker 1985:310-323). This imagery causes great confusion in African communities. The danger is always there that Jesus would be confused with a sorcerer. Finally, I wish to add that Jesus also made valuable contributions to the socioreligious reconstruction of sickness. His contributions are more holistic than that which a diviner could present to families. He concentrated on the contexts of sin, shame and exclusion. ${ }^{15}$ In the anti-Western and anti-Christian discourses holism has become a buzz-word that is used constantly (cf. Brand 2002:103-106). It is my conviction, however, that no healer can be compared to Jesus when it comes to a holistic approach. He restored family ties and relationships (Lk 7:11-17; 9:37-45) and people's position in society (17:11-19), He tended to the powerful as well as ordinary, insignificant people (Lk 7:1-10; 13:10-17), He demonstrated His power and supremacy over evil forces (Lk 9:37-45; 13:32), He combined healing and prophecy (Lk 13:32) as well as healing and counselling (Lk 5:17-26), He never exploited people (Lk 8:26-39) and He did not make false promises (Lk 9:37-45).

14.Cf. Van Wyk (2004:1210-1212, 2009a:17-20) for the differences between a herbalist and a diviner.

15.Cf. Luke 4:38-44; 5:1-11; 5:17-26.

\section{Conclusion}

Every epoch had its own approach to the miracles and exorcisms of Jesus. Today, a fair amount of consensus exists that we should follow a hermeneutical approach to miracles, this after periods during which the emphasis was either on dogmatics or critique or literature (Léon-Dufour, cf. Weder 1992:89). The present-day effort tries to create a relationship between the biblical message and the 'rationality' of the present time and context. Our question is, 'under what conditions could we allow the miracles to say what they have to say'? I have argued that it would still be possible and necessary to articulate the message about Jesus and his healings from a 'Western medical perspective'. However, I have also argued that the African context would include the living realities of primal religiosity. Should we refuse to interface with this challenge, we would not stimulate Reformed mission in Africa.

Reformed missiology in Africa has to demonstrate a willingness to listen to, respect and accommodate indigenous knowledge systems. However, the expectations coming forth from the processes of indigenisation and contextualisation would, to my mind, be too ambitious and even unrealistic. One last example should be sufficient: Students and ministers of the Maranatha Reformed Church of Christ constantly remind us that Africans want to see, touch and hear something of divine intervention and, also, that they find the Reformational dictum of 'faith alone' to be incomprehensible. On the one hand, this 'African need' could be met with references to the biblical reports: In many cases, Jesus did heal in such a way that people could 'see' the miracle (Lk 6:6-11). However, Jesus also healed without any visible sign (Lk 7:1-10). He even refused to perform miracles on demand (Lk 4:1-12), He declined the 'signdemands' / Zeichenforderung (Lk 11:29-32) and a miracle did not happen on the cross. However sympathetic one wishes to be towards African needs, these could not be accommodated at all cost. Hopefully, people in Africa would discover that signs of divine intervention remain on the horizontal level. Furthermore, faith relies on miracles, not magic, on the unexpected, not false promises of spiritual manipulation.

Despite the enormous 'success', of AIC and the charismatic movement in Africa, Reformed churches should not mislead the sick and dying with promises of miraculous healings. The magical use of muti or sacred objects (relying on the laws of causation ${ }^{16}$ ) or reliance on magic-working faith should not become our temptation. The narrative of Peter on the water (Mt 14:22-33) should constantly alert us to the difference between 'human faith' and 'divine faith'. Peter wanted to emulate Christ. He believed that everything was possible through (his) faith. What we should learn from this narrative is that there is no need to demonstrate and prove the divinity of our calling. We should rather proclaim that people who are drowning could hold on to the faithful hand of Christ (cf. Oberlinner 2007 for a complete exegetical study).

16.Causation relies either on the law of similarity or the law of contagion (cf. Van Wyk 2009a:20-22). 
It seems that we have a choice between 'success' and theological integrity. If we keep on choosing the latter, a discourse about health and healing would continue to be a discussion concerning the relationships between healing and the Kingdom (Ridderbos 1972) and healing and salvation ${ }^{17}$ (Schrage 1986; Sundermeier 2004).

The question would be whether Reformed Christians in Africa should opt for magicians and miracle workers. Should faith in the Son of God, the Son of David, the Son of Abraham, the true Adam, our great ancestor not be sufficient? Would Christian pastoral care, the deaconate and a renewed concentration on the sacraments not be sufficient? If not, we should consider innovative liturgical rituals by which 'touching the sick' could become an element of our church services (cf. Bieler 2010 for liturgical ideas). And, lastly, has the time not arrived that we should causally link certain diseases to an antinomianistic lifestyle without fear?

\section{References}

Anderson, A., 2001, African Reformation: African Initiated Christianity in the $20^{\text {th }}$ century, Africa World Press, Asmara.

Asamoah-Gyadu, J.K., 2008, “"Drinking from our own wells": The primal imagination and Christian religious innovation in contemporary Africa', Journal of African Christian Thought 11(2), 34-42.

Aulén, G., [1931] 1970, Christus Victor: An historical study of the three main types of the idea of the atonement, transl. A. Hebert, SPCK, London.

Bediako, K., 2000, 'Jesus in African culture: A Ghanaian perspective', in Jesus in Africa: The Christian gospel in African history and experience, pp. 20-33, Regnum Africa, Akropomg-Akuapem

Berends, B., 1998, 'Mission and health care', REC Mission Bulletin XVIII(2), 3-13.

Bieler, A., 2010, 'Word and touch. Ritualizing experiences of illness and healing in Christian liturgical traditions', in G. Etzelmüller \& A. Weissenrieder (Hrsg.), Religion und Krankheit, pp. 317-331, WBG, Darmstadt.

Brand, G., 2002, Speaking of a fabulous ghost: In search of theological criteria, with special reference to the debate on salvation in African Christian theology, Contributions to Philosophical Theology, vol. 7, Peter Lang, Frankfurt.

Bultmann, R., [1926] 1977, Jesus, 3. Aufl., Mohn, Gütersloh. (GTB Siebenstern 17).

Bultmann, R., [1953] 1980a, Theologie des Neuen Testaments, 8. Aufl., Mohr, Tübingen. (UTB 630)

Bultmann, R., [1933] 1980b, 'Die Frage des Wunders', in Glauben und Verstehen. Gesammelte Aufsätze. Band I., pp. 214-228, Mohr, Tübingen.

Craffert, P., 1999, Illness, health and healing in the New Testament world, Biblia Publishers, Pretoria.

Du Toit, C. \& Ngada, N. (eds.), 1999, Hearing the AIC voice, UNISA, Pretoria.

Esterbauer, R., 2007, 'Vom Wunder der Wirklichkeit zum Wunder der Sprache: Bemerkungen zu einem nicht geläufigen philosophischen Begriff', in J. Pichler \& C. Heil (Hrsg.), Heilungen und Wunder: Theologische, historische und medizinische Zugänge, pp. 14-27, WBG, Darmstadt.

Etzelmüller, G. \& Weissenrieder, A. (Hrsg.), 2010, Religion und Krankheit, WBG, Darmstadt.

Ezeh, U., 2003, Jesus Christ the ancestor: An African contextual Christology in the light of the major dogmatic Christological definitions of the church from the Council of Nicaea (325) to Chalcedon (451), Peter Lang, Bern. (Studien zur interkulturellen Geschichte des Christentums 130).

Ferdinando, K., 1999, The triumph of Christ in African perspective: A study of demonology and redemption in the African context, Paternoster Press, Carlisle.

Gnilka, J., 1990, Jesus von Nazaret: Botschaft und Geschichte, HTK Supplementband 3., Freiburg, Herder.

17.It should be clear that healing forms one aspect of salvation (Lk 4:16-21; 7:22) Preaching on salvation is therefore not complete without reference to healing and a healing ministry cannot be biblical without referral to salvation. In many healing stories there is reference not only to healing but also to salvation (Mk $5: 28 \mathrm{ff}$ ). In some passages, salvation is seen not only as healing of the sick (Mk 6:56), liberation from bleeding (Mk 5:34) and liberation from demonic possession (Lk 8:36) but also as rescue from a storm (Mt 8:25: 14:30). Sometimes salvation has to do not only with forgiveness of sins (Mk 2.5, Lk 1:77; 7.50) but also with (Lom the with communion at table (Lk 19:9). We should always remember that the fullness of salvation cannot be found in healing (Jn 5:1-9). We read of Paul (2 Cor 12:7-9), (2) 4:20) who were not healed of their diseases. In spite of that, they went on with their work in the church. Salvation is an eschatological matter, but in spite of this, Jesus and $\mathrm{h}$ disciples carried on with the healing of people on the Sabbath (Mk 3).
Goppelt, L., [1976] 1978, Theologie des Neuen Testaments, 3. Aufl., Hrsg. v J. Roloff, Vandenhoeck, Göttingen.

Helm, J., 2007, 'Wittenberger Anatomie: Motive and Ausprägung einer protestantischen Wissenschaft im 16.Jahrhundert', in S. Oehmig (Hrsg.), Medizin und Sozialwesen in Mitteldeutschland zur Reformationszeit, pp. 235-248, Evangelische Verlagsanstalt, Leipzig.

Honecker, M., 1985, 'Christus medicus', Kerygma und Dogma 31(4), 307-323.

Hoppers, C. (ed.), 2002, Indigenous knowledge and the integration of knowledge systems: Towards a philosophy of articulation, NAE, Claremont.

Jankrift, K.P., 2003, Krankheit und Heilkunde im Mittelalter, WBG, Darmstadt.

Jankrift, K.P., 2005, Mit Gott und schwarzer Magie: Medizin im Mittelalter, WBG, Darmstadt.

Jenkins, P., 2007, The next Christendom: The coming of global Christianity, 2 edn., OUP, New York NY.

Kahl, W., 2010, 'Die Bezeugung und Bedeutung frühchristlicher Wunderheilungen in der Apostelgeschichte angesichts transkultureller Übergänge', in G. Etzelmüller \& A. Weissenrieder (Hrsg.), Religion und Krankheit, pp. 249-264, WBG, Darmstadt.

Kalu, O.U., 2005, African Christianity: An African story, Department of Church History, University of Pretoria, Pretoria.

Kasper, W., [1974] 1993, Jesus the Christ, Burns \& Oates, Kent.

Kritzinger, D. (ed.), 2002, No quick fixes: The challenge of mission in a changing South Africa, IMER, Pretoria.

Maier, J., 2007, “'Ich, JHWH, bin dein Arzt!": Heilung durch Gott und ärztliche Kunst in der jüdischen Tradition', in J. Pichler \& C. Heil (Hrsg.), Heilungen und Wunder: Theologische, historische und medizinische Zugänge, pp. 60-84, WBG, Darmstadt.

Manala, M.J., 2006, 'The church's ministry to the sick in a black South African context', DTh thesis, University of South Africa.

Manda, L., 2008, 'Africa's healing wisdom: Spiritual and ethical value of traditional African healthcare practices', in R. Nicolson (ed.), Persons in community: African ethics in a global culture, pp. 125-139, University of Kwazulu-Natal Press, Scottsville.

Moltmann, J., 1989, Der Weg Jesu Christi: Christologie in messianischen Dimensionen, Kaiser, München.

Muendane, N., 2006, I am an African: Embrace your identity, escape victimisation, Soultalk CC, Buccleuch.

Ntloedibe, G., 2000, 'Ngaka and Jesus as liberators: A comparative reading', in G. West \& M. Dube (ed.), The Bible in Africa: Transactions, trajectories, and trends, pp. 498-510, Brill, Leiden.

Oberlinner, L., 2007, 'Können Wunder schief gehen?: Zu Petrus-Episode in der Seewandelgeschichte Mt 14,22-33', in J. Pichler \& C. Heil (Hrsg.), Heilungen und Wunder: Theologische, historische und medizinische Zugänge, pp. 85-104, WBG, Darmstadt.

Oehmig, S. (Hrsg.), 2007, Medizin und Sozialwesen in Mitteldeutschland zur Reformationszeit, Evangelische Verlagsanstalt, Leipzig

O'Kennedy, D., 2007, 'The metaphor of Yahweh as healer in the prophetic books of the Old Testament', In die Skriflig 41(3), 443-456.

Pannenberg, W., 1991, Systematische Theologie, Band 2, Vandenhoeck, Göttingen.

Pernkopf, E., 2007, 'Wo die Natur die gewohnte Straße verlässt: Zu Wundern in den Naturwissenschaften', in J. Pichler \& C. Heil (Hrsg.), Heilungen und Wunder: Theologische, historische und medizinische Zugänge, pp. 28-40, WBG, Darmstadt.

Pichler, J. \& Heil, C. (Hrsg.), 2007, Heilungen und Wunder: Theologische, historische und medizinische Zugänge, WBG, Darmstadt.

Porter, R., [1997] 2007, 'Die Kunst des Heilens: Eine medizinische Geschichte der Menschheit von der Antike bis heute. Übers $v$ Wissmann, J [Original title: The greatest benefit to mankind. A medical history of humanity from antiquity to the present]', Verlag HOHE, Erfstadt.

Rapp, U., 2007, 'Das Wunder ist nur im Loben zu sagen: Versuche zur Wunderrede im Buch Jesus Sirach', in J. Pichler \& C. Heil (Hrsg.), pp. 41-52, n.p.

Ridderbos, H., 1972, De komst van het koninkrijk, 2e druk, Kok, Kampen.

Rukuni, M., 2007, Being Afrikan: Rediscovering the traditional Unhu-Ubuntu-Botho pathways of being human, Mandala Publishers, Arcadia.

Schmithals, W., 1970, Wunder und Glaube: Eine Auslegung von Markus 4:35-6:6a, Neukirchener Verlag, Neukirchen-Vluyn. (Biblische Studien. Heft 59).

Schrage, W., 1986, 'Heil und Heilung', Evangelische Theologie 46, 197-214.

Sievernich, M., 2009, Die christliche Mission: Geschichte und Gegenwart, WBG, Darmstadt.

Stein, C., 2007, 'Der Leipziger Ärztestreit (1497-1501) über die "Franzosenkrankheit", in S. Oehmig (Hrsg.), Medizin und Sozialwesen in Mitteldeutschland zur Reformationszeit, pp. 215-233, Evangelische Verlagsanstalt, Leipzig.

Stinton, D., 2004, Jesus of Africa: Voices of contemporary African Christology, Orbis Books, New York.

Stuhlmacher, P., 1992, Biblische Theologie des Neuen Testaments. Band 1. Grundlegung.Von Jesus zu Paulus, Vandenhoeck, Göttingen.

Sundermeier, T., 2004, 'Heil und Heilung', Ökumenische Rundschau 35, 477-489.

Van Aarde, A.G., 2000, 'Understanding Jesus' healings', Scriptura (74), 223-236.

Van de Beek, A., 1991, Wonderen en wonderverhalen, Callenbach, Nijkerk.

Van de Beek, A .,1998, Jezus Kurios: De Christologie als hart van de theologie. Spreken over God 1, 1, 3e druk, Kok, Kampen. 
Van den End, Th \& Van't Veld, H. (red.), 2001, Met het Woord in de wereld: De Gereformeerde Zendingbond van 1901-2001, Boekencentrum, Zoetermeer.

Van Dyk, A., [1999] 2008, HIV/AIDS care and counselling: A multidisciplinary approach, 4th edn., Pearson, Cape Town.

Van Wyk, I.W.C., 2004, 'African witchcraft in theological perspective', HTS Teologiese Studies/Theological Studies 60(4), 1201-1228.

Van Wyk, I.W.C., 2009a, 'Sickness and healing in Africa: A religious perspective', in N.C. van Wyk (ed.), Integrative healthcare: A guide to meet the needs of Africa, pp. 12-30, Juta, Cape Town.
Van Wyk, I.W.C., 2009b, 'A medical ethic for a pluralistic society', in N.C. van Wyk (ed.), Integrative healthcare: A guide to meet the needs of Africa, pp. 47-64, Juta, Cape Town.

Von Bendemann, R., 2007, 'Christus der Arzt - Krankheitskonzepte in den Therapieerzählungen des Markusevangeliums', in J. Pichler \& C. Heil (Hrsg.), Heilungen und Wunder: Theologische, historische und medizinische Zugänge, pp. 105-129, WBG, Darmstadt.

Weder, H., [1982] 1992, 'Wunder Jesu und Wundergeschichten', in Einblicke ins Evangelium: Exegetische Beiträge zur neutestamentlichen Hermeneutik, pp. 61-93, Vandenhoeck, Göttingen. 